\title{
Effect of Extreme Heatwaves on the Mortality and Cellular Immune Responses of Purplish Bifurcate Mussel Mytilisepta virgata (Wiegmann, 1837) (=Septifer virgatus) in Indoor Mesocosm Experiments
}

\author{
Hyun-Ki Hong, Chang Wan Kim, Jeong-Hwa Kim, Nobuhisa Kajino and Kwang-Sik Choi* \\ Department of Marine Life Science (BK21 FOUR) and Marine Science Institute, Jeju National University, Jeju, South Korea
}

In the rocky intertidal environment, the frequency and duration of heatwaves have increased over the last decade, possibly due to global climate change. Heatwaves often result in lethal or sub-lethal disturbances in benthic animals by changing their metabolic activities. In this study, we investigated the impacts of extreme heatwave

OPEN ACCESS

Edited by:

Pengzhi Qi,

Zhejiang Ocean University, China

Reviewed by:

Mirella Vazzana,

University of Palermo, Italy

Luísa Magalhães,

University of Aveiro, Portugal

*Correspondence:

Kwang-Sik Choi

skchoi@jejunu.ac.kr

Specialty section: This article was submitted to

Marine Biology,

a section of the journa

Frontiers in Marine Science

Received: 13 October 2021 Accepted: 19 November 2021

Published: 08 December 2021

Citation:

Hong H-K, Kim CW, Kim J-H, Kajino N and Choi K-S (2021) Effect of Extreme Heatwaves on the Mortality and Cellular Immune

Responses of Purplish Bifurcate Mussel Mytilisepta virgata

Wiegmann, 1837) (=Septifer virgatus) in Indoor Mesocosm Experiments.

Front. Mar. Sci. 8:794168.

doi: 10.3389/fmars.2021.794168 stress on the hemocyte functions of Mytilisepta virgata and subsequent mortality to gain a better understanding of the potential causes and consequences of mass mortality events in this mussel during summer. We discriminated three types of hemocytes in the hemolymph, granulocytes, hyalinocytes, and blast-like cells, using flow cytometry and revealed that granulocytes were the major hemocyte involved in cellular defensive activities, such as phagocytosis and reactive oxygen species (ROS) production. For the experiment, mussels were exposed to a $40^{\circ} \mathrm{C}$ air temperature for $12 \mathrm{~h}$ per day over 5 days under laboratory conditions as a simulated semi-diurnal tidal cycle. Mortality began to occur within 3 days after beginning the experiment, and all mussels had died by the end of the experiment. Flow cytometry indicated that the mussels exposed to high air temperatures produced significantly more ROS than did the control mussels within 2 days after the onset of the experiment, which may have caused oxidative stress. Such high levels of ROS in the hemolymph increased DNA damage in hemocytes after 3 days of exposure and decreased the phagocytosis of hemocytes 4 days after the experiment began. The observed mortality and decline in immune capacity suggested that an extreme heat event occurring in the rocky intertidal ecosystem during summer could exert sublethal to lethal impacts on macrobenthic animals.

Keywords: climate change, heatwaves, intertidal mussel, lethal and sub-lethal responses, hemocyte, indoor mesocosm

\section{INTRODUCTION}

Over the last century, the earth has experienced a steady increase in temperature due to global climate change (IPCC, 2018). Concurrent with global warming, an increase in the intensity and frequency of extreme high-temperature events, referred to as heatwaves, have been observed worldwide (Easterling et al., 2000; Meehl and Tebaldi, 2004; Oliver et al., 2018; 
Smale et al., 2019; Perkins-Kirkpatrick and Lewis, 2020). Heatwaves are prolonged periods of extremely high temperatures for a particular region (Robinson, 2001). Extreme heatwaves occur occasionally worldwide. The earth's average temperature in 2018 was the fourth highest in 140 years (2018 heat wave, 2021). The summer of 2018 in the Northern Hemisphere, such as Europe, North America, and Northeast Asia, experienced extremely high temperatures (2018 heat wave, 2021). For example, in Northeast Asia, including South Korea, Japan, and China, the highest air temperature during the summer of 2018 was $>40^{\circ} \mathrm{C}$ (2018 Northeast Asia heat wave, 2021). The frequency of extreme heatwaves is expected to increase due to global warming (Perkins-Kirkpatrick and Lewis, 2020).

Extreme heatwaves can negatively affect several biological processes, drastic changes in the ecosystem's structure and function, and the marine ecosystem's goods and services (Amorim et al., 2020; Weiskopf et al., 2020; Weitzman et al., 2021). Heatwaves particularly affect intertidal shores, one of the most thermally variable and stressful habitats, resulting in lethal or sub-lethal disturbances in benthic organisms (Pansch et al., 2018; Dzwonkowski et al., 2020). Sessile invertebrates inhabiting the rocky intertidal zone are particularly vulnerable to heat due to prolonged cyclic exposure to air during low tide. Several studies have demonstrated that heatwaves are responsible for the mass mortality events in sessile invertebrates, such as barnacles [Semibalanus balanoides (Wethey, 1984)], limpets [Lottia scabra (Sutherland, 1970; Harley, 2008)], and mussels [Mytilus californianus (Harley, 2008), M. galloprovincialis (Petes et al., 2007), and M. edulis (Suchanek, 1978; Tsuchiya, 1983; Seuront et al., 2019)]. Various eco-physiological disturbances caused by heatwaves have been reported in marine invertebrates. A marked decline in energy reserves was reported in the marine gastropod Thalotia conica from Wirrina Cove in South Australia after exposure to several heatwaves (Leung et al., 2017). Heatwaves interrupt the spawning of the purple sea urchin Strongylocentrotus purpuratus (Shanks et al., 2019). Amorim et al. (2020) reported reduced phagocytic capacity and increased oxidative stress in hemocytes from the bivalve Scrobicularia plana during exposure to a heatwave.

Marine bivalves are often used as sentinel species in coastal environmental monitoring, as changes in environmental quality are often well preserved in their cells and tissues (Donaghy et al., 2009a, 2010; Vazzana et al., 2016, 2020; Parisi et al., 2017; Kim et al., 2020). The sensitivity of bivalves to environmental stressors is driven by the different structural and functional characteristics of their circulating hemocytes (Pipe and Coles, 1995; Auffret, 2005; Renault, 2015). Hemocytes are the primary cellular mediators of the defense system in marine bivalves that recognize and destroy invasive foreign material by phagocytosis, encapsulation, and production of reactive oxygen species (ROS) (Cheng, 1981; Hine, 1999; Donaghy et al., 2015). Accordingly, numerous studies have determined hemocyte activities in clams, oysters, and mussels using flow cytometry or microscopy to understand the effects of stressors caused by environmental changes (Donaghy et al., 2010, 2016; Donaghy and Volety, 2011; Hong et al., 2016).
Intertidal mussels are widely used as sentinel species in coastal environmental monitoring because they are ubiquitous fauna, able to provide a spectrum of responses to environmental stress, live a sedentary life that may explain the spatiotemporal changes in their habitat (Goldberg, 1975; Farrington et al., 2016; Beyer et al., 2017). The purplish bifurcate mussel Mytilisepta virgata (= Septifer virgatus) is distributed widely in the upper rocky intertidal zone of the northwest Pacific region from Hong Kong to northern Japan (Benard et al., 1993; Iwasaki, 1995; Kawai and Tookeshi, 2004; Lutaenko and Noseworthy, 2019; Lee et al., 2020). Similar to other mussels, the purplish bifurcate mussel has been used as a sentinel species in environmental monitoring studies due to its abundance and high tolerance to environmental stressors (Liu and Morton, 1994; Wang and Dei, 1999; Blackmore, 2001; Han et al., 2020). Under an intense heatwave, $M$. virgata may be more susceptible than other sessile benthic organisms, as they inhabit the upper intertidal area where they are exposed to the atmosphere for a prolonged period during low tide.

We attempted to understand the effect of extreme thermal stress caused by heatwaves on the immune capacity of $M$. virgata by exposing the mussel to an experimentally simulated heatwave condition for several days. Since heatwaves approaching $40^{\circ} \mathrm{C}$ have been occurring in Northeast Asia (2018 Northeast Asia heat wave, 2021), we set $40^{\circ} \mathrm{C}$ as a heatwave condition in this study. We determined hemocyte parameters, including the total hemocyte count (THC), phagocytic activity, hemocyte DNA damage, and ROS production, using flow cytometry. Here, we report the hemocyte responses of mussels exposed to extreme air temperatures and discuss the potential sublethal and lethal effects of extreme heatwave stress on upper intertidal sessile organisms.

\section{MATERIALS AND METHODS}

\section{Sampling Effort}

The purplish bifurcate mussels used in the experiment were collected from a rocky intertidal beach on the south coast of Jeju Island $\left(33^{\circ} 14^{\prime} 25^{\prime \prime} \mathrm{N}, 126^{\circ} 19^{\prime} 53^{\prime \prime} \mathrm{E}\right)$ during March and April 2019 (Figure 1). The mussels were transported to the laboratory within $2 \mathrm{~h}$ under cool conditions $\left(4-6^{\circ} \mathrm{C}\right)$ and maintained in a tank with aerated seawater (salinity 32 ; water temperature $20^{\circ} \mathrm{C}$ ) over $48 \mathrm{~h}$ to minimize physiological stress induced during sampling and transportation. The length of the shell (i.e., the longest axis of the shell) of the mussels used in the experiment ranged from 32.1 to $43.7 \mathrm{~mm}$, with a mean of $37.5 \mathrm{~mm}$.

\section{Hemocyte Characterization Hemolymph Collection}

Hemolymph was collected from the adductor muscle using a syringe fitted with a $22 \mathrm{G} \times 11 / 4^{\prime \prime}$ needle. The hemolymph was filtered through $60-\mu \mathrm{m}$ nylon mesh and then transferred directly into microtubes on ice to minimize aggregation of the hemocytes. Twenty mussels were used to characterize the hemocyte parameters by light microscopy and flow cytometry. All subsequent analyses were performed individually. 


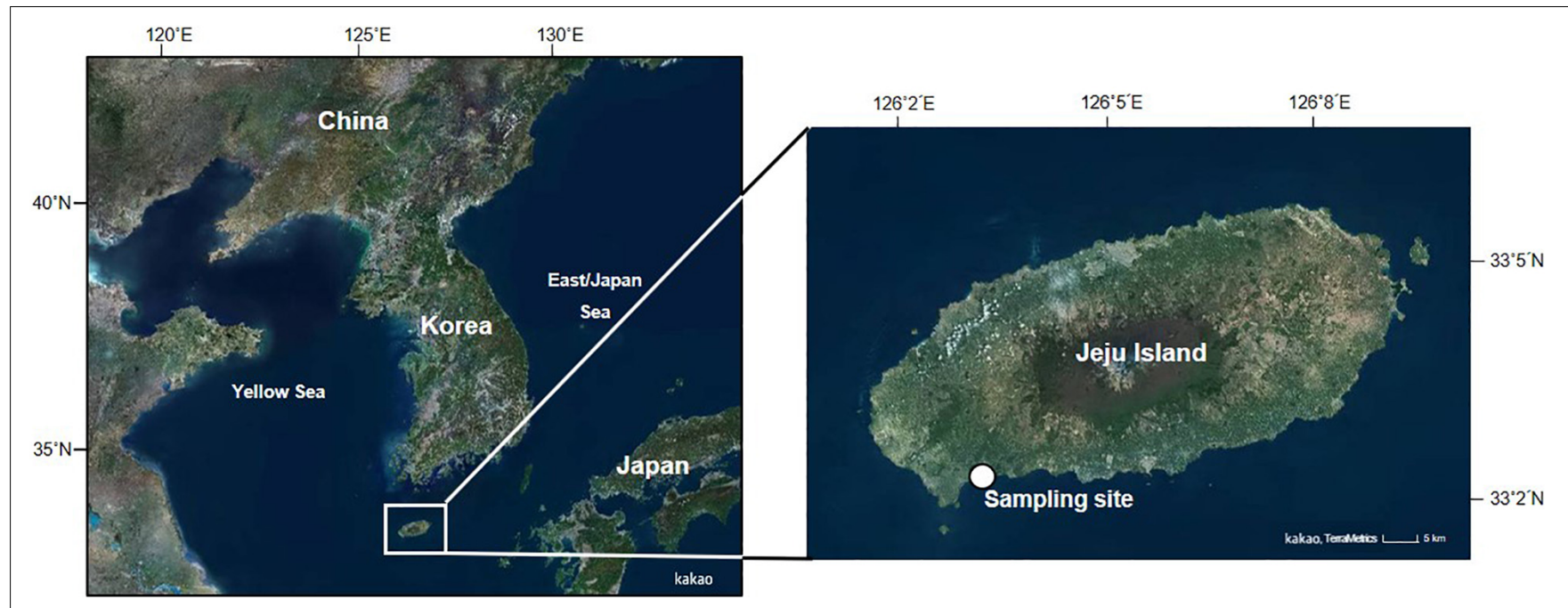

FIGURE 1 | Map showing the location of the mussel sampling sites. Mytilisepta virgata were collected from the rocky intertidal area of Hwansun, located on the southern coast of Jeju Island.

\section{Characterization of the Hemocytes by Light Microscopy}

The protocol was adapted from Hong et al. (2019). The harvested hemolymph was placed on glass poly-L-lysine-coated slides and incubated for $30 \mathrm{~min}$ in a humidity chamber at room temperature. The adherent hemocytes were fixed in absolute methanol and stained with the Hemacolor reagent (Merck, Darmstadt, Germany). The morphology of the stained hemocytes was examined under a light microscope, and the images were digitized using a digital camera. The cell and nucleus diameters were measured from the digitized images prepared using image analysis software (Image J 1.43u).

\section{Characterization of Hemocytes by Flow Cytometry}

The hemocyte parameters, including hemocyte type and count, phagocytic and oxidative capacities, and lysosome content, were analyzed using the CytoFLEX flow cytometer (Beckman Coulter, Brea, CA, United States) equipped with two active lasers (488and $639-\mathrm{nm}$ ) and four channels to detect fluorescence. The flow cytometric protocols were adapted from Yang et al. (2015).

The hemocyte type and count were determined using the fluorescent dye SYBR Green I (Sigma-Aldrich, St. Louis, MO, United States), which binds to double-stranded DNA. The hemocyte subtypes were discriminated by relative cell size and the internal complexity obtained from the forward- and side-scatter detectors. The total hemocyte count (THC) was expressed as the number of cells/mL hemolymph. The phagocytic capacity of the hemocytes was determined based on the capacity of the hemocytes to internalize fluorescence-labeled latex beads $(2 \mu \mathrm{m}$ diameter; Polysciences Inc., Warrington, PA, United States). The phagocytic capacity was expressed as the percentage of cells that engulfed beads. Finally, the oxidative capacity of the hemocytes was evaluated using the $2^{\prime} 7^{\prime}$-dichlorodihydrofluorescein diacetate fluorescent probe (Invitrogen, Carlsbad, CA, United States). Oxidative capacity was expressed as the level of green fluorescence in arbitrary units (A.U.). The phagocytic and oxidative activities of the hemocytes were induced for $180 \mathrm{~min}$ in the dark at room temperature. The number of lysosomes in the hemocytes was determined using the LysoTracker Red fluorescent staining solution (Molecular Probes, Sunnyvale, CA, United States), which permeates the hemocyte membrane and stains the lysosomal compartments. The number of lysosomal components in the hemocytes was expressed as the red fluorescence level in A.U.

\section{Heatwave Exposure Experiment Experimental Setup}

Figure 2 demonstrates the experimental setup used in the heatwave exposure experiment. A total of 100 randomly selected mussels were kept in a $10-\mathrm{L}$ plastic container filled with $7 \mathrm{~L}$ aerated seawater. The experimental tank was placed in a laboratory incubator, and the air temperature was held constant at $40^{\circ} \mathrm{C}$. The mussels were acclimated for 6 days to laboratorysimulated tidal cycles (two low and two high tides per day), corresponding to the typical semi-diurnal tidal regime in the sampling area. An electric water pump moved the water between the primary tank with mussels and the reservoir tank. The pump drained the water in the primary tank to a level exposing the mussels during the simulated low tide and pumped the water from the reservoir tank back into the primary tank to submerge the mussels during high tide. An analog timer was used to regulate the water between the primary and reservoir tanks every $6 \mathrm{~h}$. As a control, 100 mussels were kept in a 10-L plastic container filled with $7 \mathrm{~L}$ aerated seawater held at room temperature $\left(20^{\circ} \mathrm{C}\right)$. The seawater in the reservoir tank was changed every day during low tide conditions. Air and seawater temperature and salinity were recorded using YSI 85 multi-parameter probes (Rickly Hydrological Co., Columbus, $\mathrm{OH}$, United States). We did not feed the mussels during the experiment. Prior to the experiment, five mussels from the 

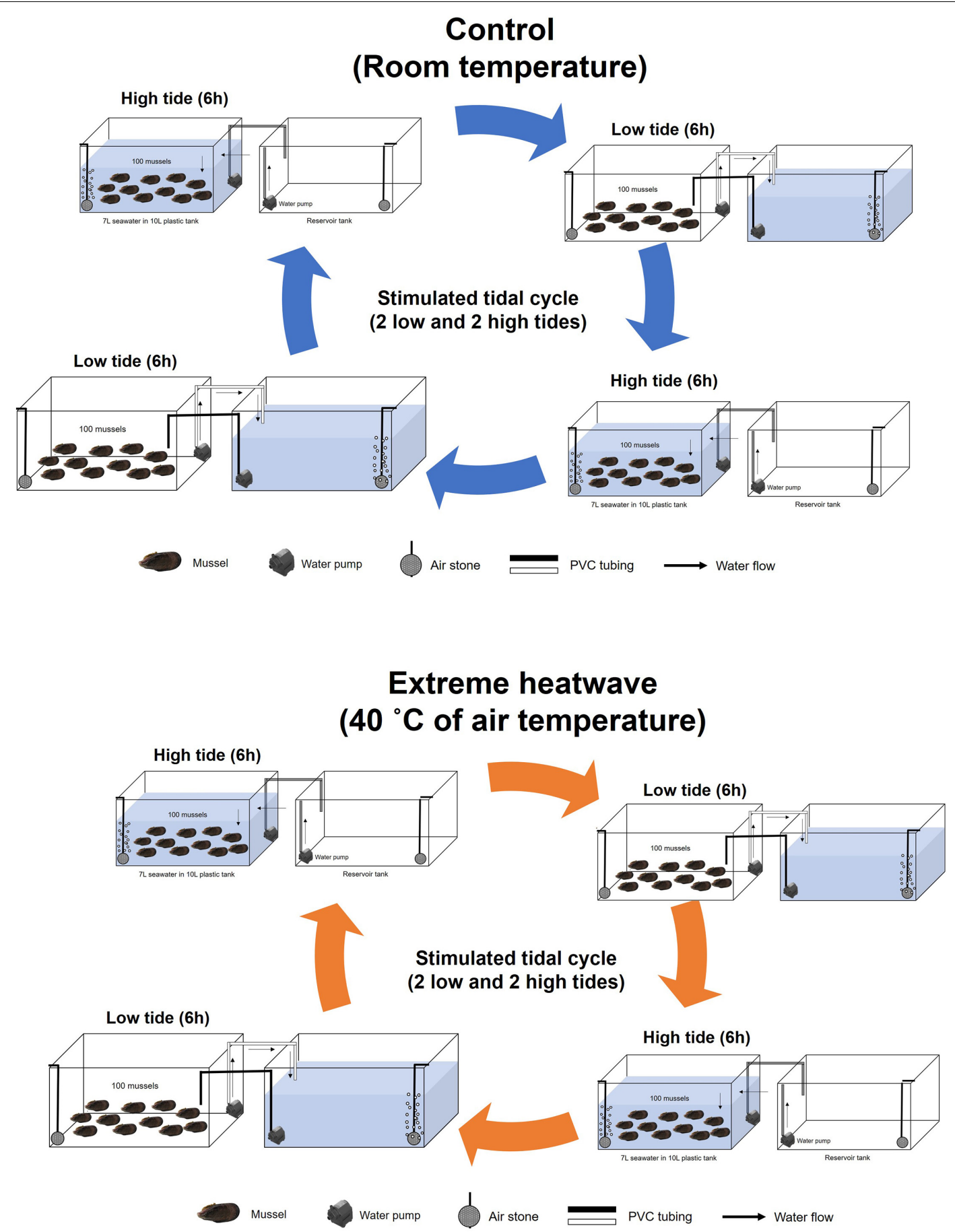

FIGURE 2 | Experimental setups used in the heatwave exposure experiment.

control tank were used to measure the hemocyte response before exposure. Table 1 summarizes the air and seawater temperatures and salinity determined at each sampling time.

The analyses were started $6 \mathrm{~h}$ after the end of the first high tide. From then on, the mussels were collected every $12 \mathrm{~h}$ at the end of one cycle of low tide and high tide. The experiment was conducted until $126 \mathrm{~h}$ after exposure when all mussels perished. To determine immune capacity, hemolymph was collected from five randomly selected individuals under each experimental condition after $6,18,30,42,54,66,78,90$, 102 , and $114 \mathrm{~h}$. The mussels used to collect hemolymph were removed from their respective experimental tanks. Mortality rates of mussels were recorded in each tank during each sampling period. 
TABLE 1 | Air and seawater temperature and salinity of the experimental conditions were determined at each sampling time.

\begin{tabular}{|c|c|c|c|c|c|c|}
\hline \multirow[t]{2}{*}{ Exposure time(h) } & \multicolumn{3}{|c|}{ Control } & \multicolumn{3}{|c|}{ Heatwave exposure } \\
\hline & Air temperature $\left({ }^{\circ} \mathrm{C}\right)$ & Water temperature $\left({ }^{\circ} \mathrm{C}\right)$ & Salinity & Air temperature $\left({ }^{\circ} \mathrm{C}\right)$ & Water temperature $\left({ }^{\circ} \mathbf{C}\right)$ & Salinity \\
\hline 6 & 20.1 & 21.0 & 32.3 & 40 & 31.8 & 32.1 \\
\hline 18 & 20.3 & 21.9 & 32.4 & 40 & 31.5 & 33.1 \\
\hline 30 & 20.4 & 21.5 & 32.4 & 40 & 30.6 & 33.4 \\
\hline 42 & 20.2 & 21.1 & 32.4 & 40 & 31.1 & 32.5 \\
\hline 66 & 20.4 & 20.9 & 32.2 & 40 & 30.8 & 32.6 \\
\hline 78 & 20.1 & 20.9 & 32.4 & 40 & 31.0 & 33.1 \\
\hline 90 & 20.3 & 21.4 & 32.3 & 40 & 30.1 & 32.4 \\
\hline 102 & 20.3 & 21.1 & 32.4 & 40 & 31.5 & 32.1 \\
\hline 114 & 20.4 & 20.9 & 32.1 & 40 & 31.1 & 33.8 \\
\hline 126 & 20.2 & 20.9 & 32.2 & 40 & 31.5 & 33.4 \\
\hline
\end{tabular}

\section{Hemocyte Parameter Analysis by Flow Cytometry}

The THC, hemocyte DNA damage, phagocytic capacity, and ROS production of individual mussels were determined using the CytoFLEX flow cytometer. THC, phagocytic capacity, and ROS production were measured as described in Section "Characterization of hemocytes by flow cytometry."

The percentage of hemocytes containing fragmented DNA was determined as a ratio of the hemocytes in the sub-G0 phase (i.e., hemocytes containing fragmented DNA) to hemocytes in the G1 stage in the circulating hemolymph using the red fluorescence detector on the flow cytometer. For the assay, $100 \mu \mathrm{L}$ hemolymph was mixed with $900 \mu \mathrm{L}$ cold ethanol and incubated overnight at $20^{\circ} \mathrm{C}$. After washing with phosphate-buffered saline $(0.15 \mathrm{M}$ $\mathrm{NaCl}, \mathrm{pH} 7.5$ ), the fixed and washed hemocytes were incubated with $5 \mu \mathrm{L} 10 \mathrm{mM}$ RNase A for $30 \mathrm{~min}$ at room temperature to remove RNA. The hemocytes were stained with propidium iodide (final concentration $=50 \mu \mathrm{g} / \mathrm{mL}$ ) for $30 \mathrm{~min}$ in the dark at room temperature. The percentage of the sub-G1 cell population was estimated from the flow cytometry histogram plotting the hemocyte count (y-axis) versus the amount of DNA in the cells at different cell cycle phases ( $\mathrm{x}$-axis, propidium iodide fluorescence intensity).

\section{Statistical Analysis}

We used Sigma plot 14.5 (Systat Software, Inc., San Jose, CA, United States) for the statistical analyses. Data were tested for normality and homogeneity of variance to meet the assumptions of parametric statistics. One-way analysis of variance (ANOVA) followed by Tukey's HSD test was conducted to compare the cell and nucleus diameters and nucleus/cell (N/C) ratio among hemocyte types. The Student's $t$-test was conducted to compare the phagocytic capacity, oxidative capacity, and lysosomal contents of the granulocytes with those of the hyalinocytes. To evaluate hemocyte response over time, one-way ANOVA followed by Tukey's HSD test was used to compare the hemocyte parameters of the mussels among time points within each experimental group. In addition, significant differences in the hemocyte parameters of the mussels between the control and treated groups were detected using Student's $t$-test. A $P$ value $<0.05$ was considered significant.

\section{RESULTS}

\section{Hemocyte Types}

The light microscopic analysis revealed that $M$. virgata had three distinct types of hemocytes in the hemolymph, as in other marine bivalves [Mytilus coruscus (Yang et al., 2015), Crassostrea gigas (Donaghy et al., 2010), C. ariakensis (Donaghy et al., 2009b), C. nippona (Hong et al., 2014), Saccostrea kegaki (Hong et al., 2013), S. glomerata (Aladaileh et al., 2007), Ostrea circumpicta (Hong et al., 2013), Hyotissa hyotis (Hong et al., 2013), Anodonta cygnea (Jamili et al., 2009)], including granulocytes, hyalinocytes, and blast-like cells (Figure 3). The granulocytes contained numerous granules in the cytoplasm, and several long pseudopodia were attached to the surface. The hyalinocytes included long pseudopodia on the cell surface, while none or a few pseudopodia were in the cytoplasm. The blast-like cells were small and round, with very thin cytoplasm. The flow cytometry analysis discriminated the three distinct types of hemocytes based on their relative cell size and internal complexity. The THC ranged from $0.4 \times 10^{6}$ to $2.7 \times 10^{6}$ cells $/ \mathrm{mL}$ with a mean of $1.3 \times 10^{6}$ cells $/ \mathrm{mL}$ (Table 2 ). Granulocytes were the most abundant $(56.5 \%)$ cells in the hemolymph, followed by hyalinocytes (29.3\%) and blast-like cells (12.6\%, Table 2 ).

Table 3 summarizes the size of the cells and the nucleus and the nucleus/cell size ratio of the three types of hemocytes, as determined from the light microscopic images. The cell and nucleus size significantly differed among the three hemocyte types, the largest of which were hyalinocytes (mean $=12.96 \mu \mathrm{m})$, while blast-like cells were the smallest (mean $=5.62 \mu \mathrm{m})$. The nucleus sizes of the granulocytes, hyalinocytes, and blast-like cells were $3.50,4.36$, and $3.98 \mu \mathrm{m}$. Consequently, the nucleus/cell size ratio of blast-like cells (0.71) was significantly higher (oneway ANOVA, $P<0.05)$ than those of granulocytes $(0.40)$ and hyalinocytes (0.34).

\section{Immunological Activities}

Both granulocytes and hyalinocytes exhibited some phagocytic activity, while blast-like cells did not. The phagocytic capacity of granulocytes $(39 \%)$ was significantly higher than that of hyalinocytes (7.4\%, Student's t-test, $P<0.05$, Figure 4A). 


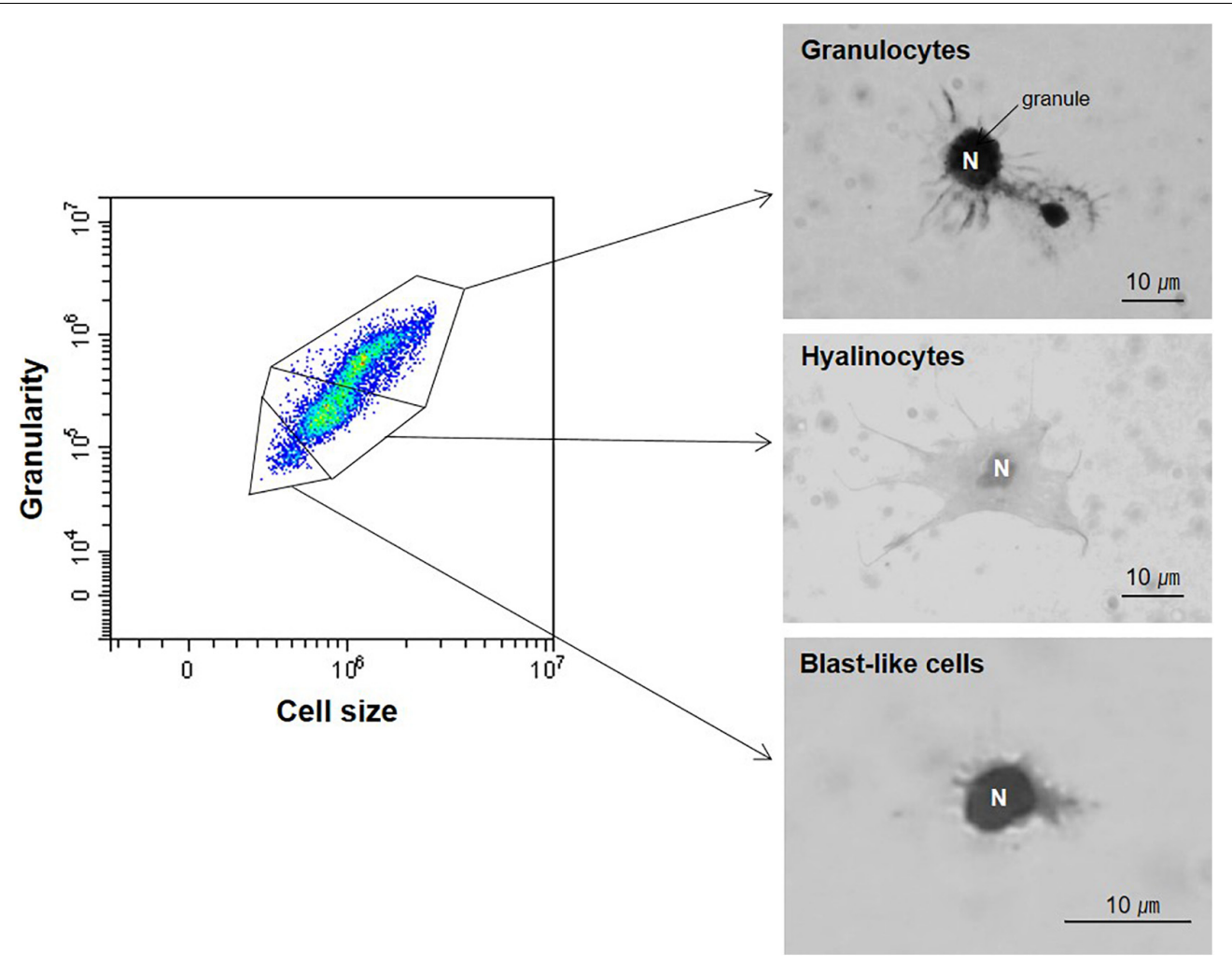

FIGURE 3 | Three hemocyte types from Mytilisepta virgata were determined using a combination of flow cytometry and light microscopy. N, nucleus.

The oxidative capacity was significantly higher in granulocytes $\left(6.4 \times 10^{4}\right.$ A.U. $)$ than hyalinocytes $\left(3.2 \times 10^{4}\right.$ A.U., Student's t-test, $P<0.05$, Figure 4B). Granulocytes $\left(1.7 \times 10^{5}\right.$ A.U.) contained significantly more lysosomes than hyalinocytes $\left(0.7 \times 10^{5}\right.$ A.U., Student's t-test, $P<0.05$, Figure 4C). Granulocytes exhibited higher phagocytic activity, oxidative capacity, and lysosomal content compared with hyalinocytes. Based on the flow cytometry analysis, granulocytes were the main hemocytes involved in $M$. virgata cellular defense, while blast-like cells may not be directly involved in the cell-mediated immune response.

\section{Effects of Heatwave Stress Cumulative Mortality}

No mortality was observed over the 126-h experiment in the control tank. In contrast, mortality began to occur $66-\mathrm{h}$ after

TABLE 2 | Total hemocyte count (THC), mortality, and percentage of each population.

\begin{tabular}{lcccc}
\hline & N & Mean \pm SE & Min & Max \\
\hline THC (cells/ml) & 20 & $1.3 \times 10^{6} \pm 1.5 \times 10^{5}$ & $3.5 \times 10^{5}$ & $2.7 \times 10^{6}$ \\
Mortality (\%) & 20 & $0.9 \pm 0.2$ & 0.2 & 4.5 \\
Granulocytes (\%) & 20 & $56.5 \pm 1.8$ & 44.2 & 79.0 \\
Hyalinocytes (\%) & 20 & $29.3 \pm 1.9$ & 11.6 & 45.5 \\
Blast-like cells (\%) & 20 & $12.6 \pm 1.5$ & 4.4 & 35.6
\end{tabular}

the start of the experiment in the heat-exposed tank $(7.1 \%$, Figure 5). Then, the cumulative mortality increased dramatically, and all mussels died within $126 \mathrm{~h}$ after the initiation of heatwave stress (Figure 5).

\section{Total Hemocyte Count}

Before the experiment, the THC in the mussels ranged from $0.8 \times 10^{6}$ to $1.4 \times 10^{6}$ cells $/ \mathrm{mL}$, with a mean of $1.1 \times 10^{6}$ cells/mL (Figure 6A). The THC of the control mussels did not vary significantly during the experiment. In contrast, the THC of the heatwave-exposed mussels fluctuated $30 \mathrm{~h}$ after the onset of the experiment. After $6 \mathrm{~h}$ of exposure, the THC of the mussels in the heatwave tank increased significantly $\left(1.7 \times 10^{6}\right.$ cells $/ \mathrm{mL}$, Student's $t$-test, $P<0.05)$ compared with the control, and then declined to a value $\left(0.8 \times 10^{6}\right.$ cells $\left./ \mathrm{mL}\right)$ similar to that of the control at $30 \mathrm{~h}$ (Figure 6A). From 30 to $114 \mathrm{~h}$ after the onset of the experiment, the THC did not differ significantly between the heatwave-exposed and control mussels, ranging from $0.8 \times 10^{6}$ to $1.4 \times 10^{6}$ cells $/ \mathrm{mL}$ (Figure $\mathbf{6 A}$ ).

\section{Reactive Oxygen Species Production}

At the beginning of the experiment, ROS production by hemocytes ranged from $0.7 \times 10^{5}$ to $2.2 \times 10^{5}$ A.U., with a mean of $1.4 \times 10^{5}$ A.U. (Figure 6B). Over the $114 \mathrm{~h}$ experiment, the ROS production by hemocytes in the control mussels remained stable, ranging from $1.4 \times 10^{5}$ A.U. $(42 \mathrm{~h})$ to $2.8 \times 10^{5}$ A.U. (114 h; Figure 6B). In contrast, the ROS production of hemocytes 
TABLE 3 | Cell and nucleus diameters and nucleus/cell (N/C) ratio.

\begin{tabular}{|c|c|c|c|c|c|c|c|c|c|c|}
\hline & \multirow[t]{2}{*}{$\mathbf{N}$} & \multicolumn{3}{|c|}{ Cell $(\mu \mathrm{m})$} & \multicolumn{3}{|c|}{ Nucleus ( $\mu \mathrm{m})$} & \multicolumn{3}{|c|}{ N/C ratio } \\
\hline & & Mean \pm SE & Min & $\operatorname{Max}$ & Mean \pm SE & Min & Max & Mean \pm SE & Min & Max \\
\hline Granulocytes & 20 & $8.93^{b} \pm 0.31$ & 6.50 & 11.80 & $3.56^{b} \pm 0.15$ & 3.09 & 5.98 & $0.40^{b} \pm 0.02$ & 0.30 & 0.62 \\
\hline Hyalinocytes & 20 & $12.96^{a} \pm 0.43$ & 9.83 & 15.75 & $4.36^{a} \pm 0.15$ & 3.59 & 5.90 & $0.34^{c} \pm 0.01$ & 0.24 & 0.46 \\
\hline Blast-like cells & 10 & $5.62^{\mathrm{C}} \pm 0.18$ & 4.55 & 6.22 & $3.98^{\mathrm{ab}} \pm 0.14$ & 3.55 & 4.81 & $0.71^{\mathrm{a}} \pm 0.02$ & 0.61 & 0.80 \\
\hline
\end{tabular}

Different letter $(\mathrm{a}-\mathrm{c})$ represent significant (one-way ANOVA, $P<0.05$ ) differences among hemocyte types.

A

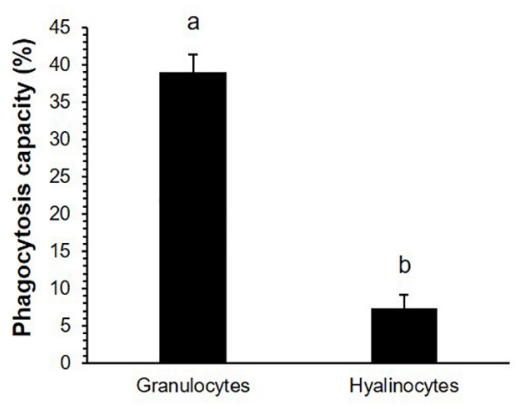

B

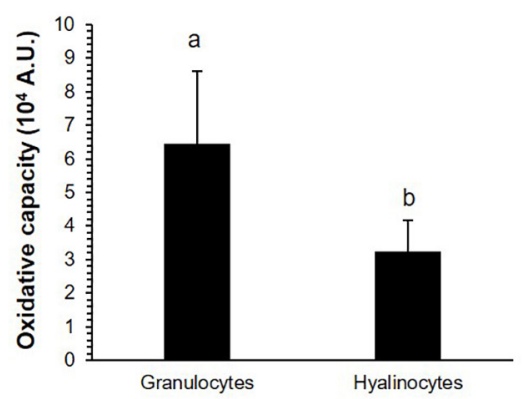

C

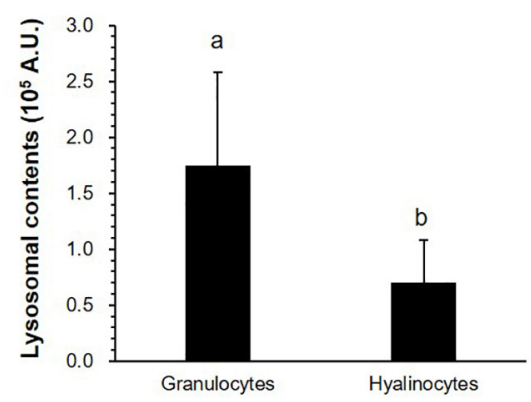

FIGURE 4 | (A) Phagocytosis capacity, (B) oxidative capacity, and (C) lysosomal contents in granulocytes and hyalinocytes of Mytilisepta virgata determined by flow cytometry. Values are presented as the mean \pm standard error. Different letters in the columns represent significant $(t$-test, $P<0.05)$ differences between the granulocytes and hyalinocytes.

in the mussels exposed to heatwave stress increased rapidly from the beginning of the experiment $\left(1.4 \times 10^{5}\right.$ A.U. $)$ to $18 \mathrm{~h}$ $\left(4.0 \times 10^{5}\right.$ A.U. $)$ and then to $42 \mathrm{~h}\left(4.3 \times 10^{5}\right.$ A.U.; Figure $\left.6 \mathrm{~B}\right)$. Then, ROS production by the hemocytes in the treated mussels declined to that in the control mussels (Figure 6B).

\section{Hemocyte DNA Damage}

The percentage of fragmented DNA (sub-G0/G1) in the hemocytes before the experiment ranged from 9.0 to $18.9 \%$, with a mean of $13.3 \%$ (Figure 6C). Over the $114 \mathrm{~h}$ experiment, the percentage of damaged DNA remained stable in the control mussels, ranging from $3.6 \%(18 \mathrm{~h})$ to $16.9 \%(66 \mathrm{~h}$;

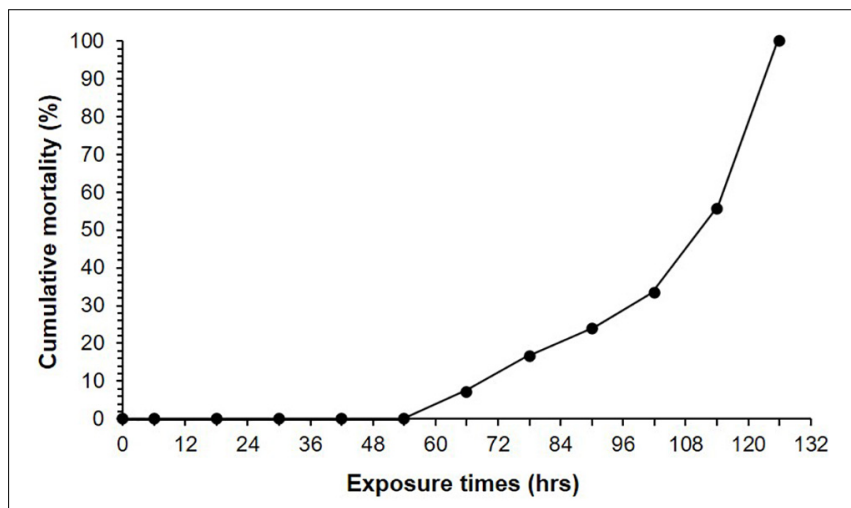

FIGURE 5 | Cumulative mortality of Mytilisepta virgata. Mortality was monitored after $6,18,30,42,54,66,78,90,102,114$, and 126 h under heatwave exposure.
Figure 6C). However, the percentage of damaged DNA in the heatwave-exposed mussels was significantly higher (Student's $t$-test, $P<0.05)$ from $78 \mathrm{~h}(20 \%)$ to the end of the experiment (i.e., 114 h, 31.6\%; Figure 6C).

\section{Phagocytic Capacity}

The granulocytes displayed limited phagocytic capacity, and the hyalinocytes and blast-like hemocytes were not actively engaged in phagocytosis. At the beginning of the experiment, the mean phagocytic capacity of the granulocytes was $40.2 \%$ (Figure 6D). The phagocytic capacity of granulocytes from the control mussels remained stable over the $114 \mathrm{~h}$ experiment, ranging from 36.2 to $54.8 \%$ (Figure 6D). In contrast, the phagocytic capacity of the heatwave-exposed mussels decreased significantly at $18 \mathrm{~h}$, from 38.5 to $25.8 \%$ (Student's $t$-test, $P<0.05$; Figure 6D). The phagocytic capacity of the mussels in the heatwave exposure tank recovered after $30 \mathrm{~h}$, and there was no significant difference from that of the control mussels until $90 \mathrm{~h}$. The phagocytic capacity of the heatwave-exposed mussels decreased again, beginning at $30 \mathrm{~h}$ until the end of the experiment (19.4\%, Figure 6D).

\section{DISCUSSION}

In this experiment, the $40^{\circ} \mathrm{C}$ air temperature set for the heatwave stress increased the seawater temperature from 20 to $30^{\circ} \mathrm{C}$. Accordingly, the $M$. virgata used in this study were exposed to $40^{\circ} \mathrm{C}$ air and $30^{\circ} \mathrm{C}$ seawater every $6 \mathrm{~h}$ over 6 days. The onset of mussel mortality occurred $66 \mathrm{~h}$ after exposure to the heatwave, and all mussels in this treatment perished between 114 and $126 \mathrm{~h}$. Several studies have documented the lethal water 

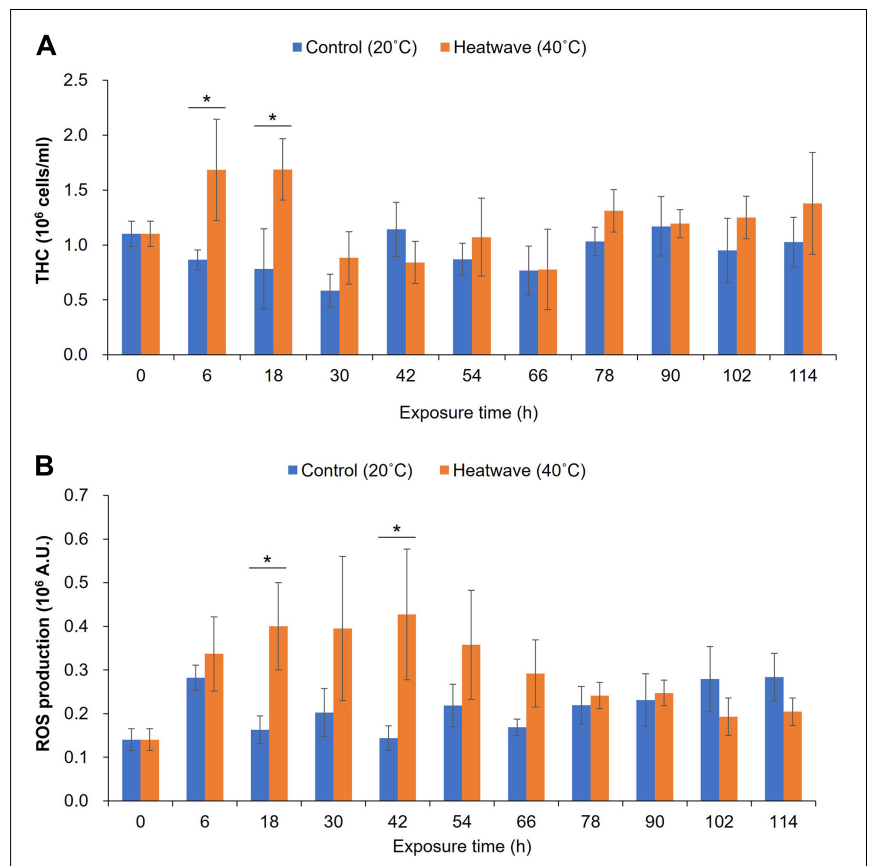

C $\quad$ Control $\left(20^{\circ} \mathrm{C}\right) \quad$ Heatwave $\left(40^{\circ} \mathrm{C}\right)$

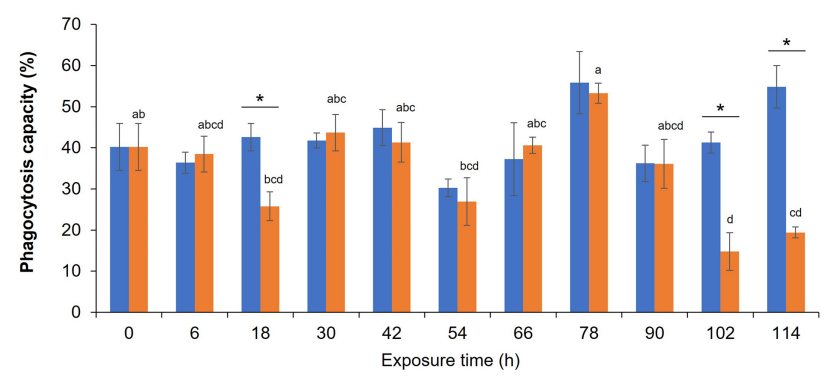

D $\quad=$ Control $\left(20^{\circ} \mathrm{C}\right) \quad=$ Heatwave $\left(40^{\circ} \mathrm{C}\right)$

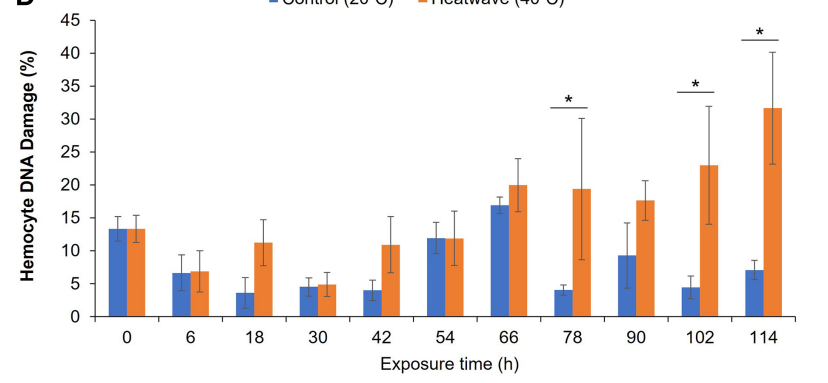

FIGURE 6 | (A) Total hemocyte count, (B) reactive oxygen species (ROS) production, (C) phagocytosis capacity, and (D) DNA damage of hemocytes of Mytilisepta virgata. Values are presented as the mean \pm standard error. Asterisk $\left(^{\star}\right)$ represents significant $(t$-test, $P<0.05)$ differences between control and treatment. Different letters (a-d) on histograms indicate statistical (one-way ANOVA, $P<0.05$ ) differences among exposure times within each experimental group.

and air temperatures for Mytilus species. Caciun (1980) reported that $30^{\circ} \mathrm{C}$ is a lethal water temperature for M. galloprovincialis living in the sublittoral zone of the Baltic Sea. The lethal water temperature for $M$. edulis has been estimated to be $25-28^{\circ} \mathrm{C}$ on the east coast of the United States (Well and Gray, 1960;
Wallis, 1975; Gonzalez and Yevich, 1976; Incze et al., 1980). Jansen et al. (2007) demonstrated that the median lethal air temperature for Mytilus species in a $24 \mathrm{~h}$ experiment is $30-$ $31^{\circ} \mathrm{C}$. Although no studies are available on the lethal temperature of Mytilisepta species, Tsuchiya (1983) reported that the heat tolerance of Mytilisepta (Septifer) in the upper intertidal zone is higher than that of Mytilus in the lower intertidal zone. In agreement with Tsuchiya (1983), our data suggest that the lethal air temperature and lethal seawater temperature of $M$. virgata are relatively higher than the previously reported lethal temperatures of Mytilus species.

Studies on the hemocyte responses of marine mollusks are useful for evaluating the physiological status of marine mollusks against environmental disturbances (Pipe and Coles, 1995; Auffret, 2005; Renault, 2015). Accordingly, we analyzed the hemocyte parameters of $M$. virgata to evaluate the physiological response to thermal shock by simulating a heatwave during a semi-diurnal tidal cycle. During the first day of heatwave exposure, the THC of the mussels exposed to the heatwave increased significantly from $1.1 \times 10^{6}$ to $1.7 \times 10^{6} \mathrm{cells} / \mathrm{m}$, which was more than twice as high as the control mussels. An increase in the THC is considered a consequence of proliferation or movement of cells from the tissues into the hemolymph in marine bivalves, whereas decreases are likely due to cell lysis or increased movement of cells from the hemolymph to the tissues (Pipe and Coles, 1995; Matozzo et al., 2012). Several studies have reported that acute temperature increases lead to an increased THC in the circulating hemolymph of the mussel M. galloprovincialis (Rahman et al., 2019), oyster Crassostrea gigas (Rahman et al., 2019), cockle Katelysia rhytiphora (Rahman et al., 2019), clams Chamelea gallina (Monari et al., 2007; Matozzo and Marin, 2011), Mactra quadrangularis (Yu et al., 2009), and Ruditapes philippinarum (Paillard et al., 2004), and scallop Azumapecten farreri (Chen et al., 2007). Chen et al. (2007) and Monari et al. (2007) hypothesized that the increase in the THC in response to an acute temperature increase could be a consequence of mobilization of cells from the tissues to the hemolymph in response to bacteria. Monari et al. (2007) observed a significant number of bacteria surrounding the hemocytes of the clam C. gallina exposed to a water temperature of $30^{\circ} \mathrm{C}$. Therefore, the observed increase in the THC in the circulating hemolymph during the first day of heatwave exposure in this study was probably due to hemocytes mobilized from surrounding tissues into the hemolymph in response to a large number of bacteria in the hemolymph.

Thermal stress often induces excessive ROS production in the circulating hemocytes of marine bivalves, including the mussels M. edulis (Wu et al., 2016), M. galloprovincialis (Rahman et al., 2019), and M. coruscus (Mackenzie et al., 2014), oyster C. gigas (Hégaret et al., 2003; Rahman et al., 2019), cockle K. rhytiphora (Rahman et al., 2019), and scallop C. farreri (Chen et al., 2007). Excessive ROS production disrupts cellular structure and function, resulting in fragmented DNA (Bolognesi and Cirillo, 2014; Nikitaki et al., 2015; Hong et al., 2019). In the present study, the flow cytometry analysis indicated that the heatwave-exposed mussels produced significantly more ROS compared with the control mussels within $42 \mathrm{~h}$ of experimental onset. Furthermore, 
a drastic increase in DNA damage in hemocytes was observed in mussels subjected to the heatwave conditions $72 \mathrm{~h}$ after onset of the experiment, suggesting that heatwave stress triggers a high level of ROS in hemocytes, which led to an increase in DNA fragmentation in hemocytes.

Phagocytosis in marine bivalves is a major immune function that is sensitive to internal and external stressors (Donaghy et al., 2009a; Hégaret et al., 2011; Jauzein et al., 2013; SilvaAciares et al., 2013). In the present study, the phagocytic capacity of the granulocytes from mussels exposed to high air temperature significantly decreased $102 \mathrm{~h}$ after the experiment started. Notably, the phagocytic capacity of the granulocytes from the mussels under the heatwave condition decreased to onethird of the values in control mussels. Similarly, Amorim et al. (2020) reported that the clam Scrobicularia plana, exposed to a marine heatwave environment with a water temperature of $8^{\circ} \mathrm{C}$, suffered significantly inhibited phagocytic activity. A sudden increase in water temperature acts as a stressor that leads to a substantial decrease in the phagocytic capacity of the mussel M. galloprovincialis (Mosca et al., 2013), oysters C. gigas (Gagnaire et al., 2006) and C. virginica (Hégaret et al., 2003), and clams C. gallina (Monari et al., 2007) and M. veneriformis (Yu et al., 2009). Gagnaire et al. (2006) highlighted that the decrease in phagocytic capacity in C. gigas exposed to high temperatures is due mainly to increased mortality of hemocytes. In this study, the reduction in the phagocytic capacity of $M$. virgata exposed to the heatwave coincided with increased hemocyte DNA damage. The extent of DNA damage in $M$. virgata exposed to the heatwave increased dramatically, from 11.9 to $20 \%$ within 66 h of exposure, ultimately reaching $31.6 \%$ at $114 \mathrm{~h}$. Therefore, a significant level of DNA fragmentation occurred in hemocytes during this period and may be responsible for the decreased phagocytic capacity of M. virgata.

\section{CONCLUSION}

Mussels exposed to extreme heatwave stress exhibited a drastic increase in ROS production and hemocyte DNA damage and a significant decrease in phagocytic capacity within 5 days of experimental onset, indicating that the cellular defensive

\section{REFERENCES}

2018 heat wave (2021).Available from https://en.wikipedia.org/wiki/2018_heat_ wave\#cite_note-2 (accessed date July 15, 2021).

2018 Northeast Asia heat wave (2021). Available from https://en.wikipedia.org/ wiki/2018_Northeast_Asia_heat_wave (accessed July 11, 2021).

Aladaileh, S., Nair, S. V., and Birch, D. (2007). Sydney rock oyster (Saccostrea glomerata) hemocytes: morphology and function. J. Invert. Pathol. 96, 48-63. doi: 10.1016/j.jip.2007.02.011

Amorim, V. E., Goncalves, O., Capela, R., Fernández-Boo, S., Oliveira, M., Dolbeth, M., et al. (2020). Immunological and oxidative stress responses of the bivalve Scrobicularia plana to distinct patterns of heatwaves. Fish Shellfish Immunol. 106, 1067-1077. doi: 10.1016/j.fsi.2020.09.024

Auffret, M. (2005). "Chapter 3. Bivalves as models for marine immunotoxicology," in Investigative Immunotoxicology, eds H. Tryphonas, M. Fournier, B. R. Blakley, J. E. G. Smits, and P. Brousseau (London: Taylor and Francis), 29-44. doi: $10.1201 / 9781420036817 . c h 3$ activities of $M$. virgata are susceptible to heatwaves. The mortality and decreased immune capacity in this study suggest that extreme heat events in the rocky intertidal ecosystem during the summer may exert sublethal to lethal impacts on sessile invertebrates. Furthermore, macrobenthic animals may become more susceptible to secondary stressors in extreme heatwave events in a global climate change scenario.

\section{DATA AVAILABILITY STATEMENT}

The raw data supporting the conclusions of this article will be made available by the authors, without undue reservation.

\section{AUTHOR CONTRIBUTIONS}

$\mathrm{H}-\mathrm{KH}$ and K-SC designed the study. H-KH, CK, J-HK, and $\mathrm{NK}$ processed and analyzed the datasets and worked on interpretations of the results with K-SC. H-KH wrote the manuscript. K-SC reviewed the manuscript. All authors contributed to the article and approved the submitted version.

\section{FUNDING}

This study was supported by the Basic Science Research Program through the National Research Foundation of Korea (NRF), funded by the Ministry of Education (Grant No. 2019R1A6A1A03033553) and the Ministry of Science and ICT (Grant No. 2021R1C1C2004304).

\section{ACKNOWLEDGMENTS}

We are indebted to the Shellfish Aquaculture and Research Laboratory staff at Jeju National University for their support during the experiment. The English in this document has been checked by at least two professional editors, both native speakers of English. For a certificate, please see: http://www.textcheck. com/certificate/1ERw5I.

Benard, F. R., Cai, Y. Y., and Morton, B. (1993). A catalogue of the living marine bivalve molluscs of China. Hong Kong: Hong Kong University Press.

Beyer, J., Green, N. W., Brooks, S., Allan, I. J., Ruus, A., Gomes, T., et al. (2017). Blue mussels (Mytilus edulis spp.) as sentinel organisms in coastal pollution monitoring: A review. Mar. Environ. Res. 130, 338-365. doi: 10.1016/ j.marenvres.2017.07.024

Blackmore, G. (2001). Interspecific variation in heavy metal body concentrations in Hong Kong marine invertebrates. Env. Pollut. 114, 303-311. doi: 10.1016/ s0269-7491(01)00086-0

Bolognesi, C., and Cirillo, S. (2014). Genotoxicity biomarkers in aquatic bioindicators. Curr. Zool. 60, 273-284. doi: 10.1093/czoolo/60.2.273

Caciun, C. (1980). Effect of high temperature on the ultrastructure of Leydig cells in Mytilus galloprovincialis. Mar. Biol. 60, 73-79. doi: 10.1007/bf0038 9150

Chen, M., Yang, H., Delaport, M., and Zhao, S. (2007). Immune condition of Chlamys farreri in response to acute temperature challenge. Aquaculture 271, 479-487. doi: 10.1016/j.aquaculture.2007.04.051 
Cheng, T. C. (1981). “Bivalves," in Invertebrate Blood Cells, ed. N. A. R. A. F. Rowley (London: Academic Press), 233-300.

Donaghy, L., and Volety, A. K. (2011). Functional and metabolic characterization of hemocytes of the green mussel, Perna viridis: in vitro impacts of temperature. Fish Shellfish Immunol. 31, 808-814. doi: 10.1016/j.fsi.2011.07.018

Donaghy, L., Hong, H. K., Jauzein, C., and Choi, K. S. (2015). The known and unknown sources of reactive oxygen and nitrogen species in haemocytes of marine bivalve molluscs. Fish Shellfish Immunol. 42, 91-97. doi: 10.1016/j.fsi. 2014.10.030

Donaghy, L., Hong, H. K., Kim, M., Park, H. S., and Choi, K. S. (2016). Assessment of the fitness of the mussel Mytilus galloprovincialis two years after the Hebei Sprit oil spill. Mar. Pollut. Bull. 113, 324-331. doi: 10.1016/j.marpolbul.2016.10. 007

Donaghy, L., Hong, H. K., Lee, H. J., Jun, J. C., Park, Y. J., and Choi, K. S. (2010). Hemocyte parameters of the Pacific oyster Crassostrea gigas a year after the Hebei Spirit oil spill off the west coast of Korea. Helgol. Mar. Res. 64, 349-355. doi: 10.1007/s10152-010-0190-7

Donaghy, L., Lambert, C., Choi, K. S., and Soudant, P. (2009a). Hemocytes of the carpet shell clam (Ruditapes decussatus) and the Manila clam (Ruditapes philippinarum): Current knowledge and future prospects. Aquaculture 297, 10-24. doi: 10.1016/j.aquaculture.2009.09.003

Donaghy, L., Kim, B. K., Hong, H. K., Park, H. S., and Choi, K. S. (2009b). Flow cytometry studies on the populations and immune parameters of the hemocytes of the Suminoe oyster, Crassostrea ariakensis. Fish Shellfish Immunol. 27, 296-301. doi: 10.1016/j.fsi.2009.05.010

Dzwonkowski, B., Coogan, J., Fournier, S., Lockridge, G., Park, K., and Lee, T. (2020). Compounding impact of severe weather events fuels marine heatwave in the coastal ocean. Nat. Commun. 11:4623. doi: 10.1038/s41467-020-18339-2

Easterling, D. R., Meehl, G. A., Parmesan, C., Changnon, S. A., Karl, T. R., and Mearns, L. O. (2000). Climate extremes: observations, modeling, and impacts. Science 289, 2068-2074. doi: 10.1126/science.289.5487.2068

Farrington, J. W., Tripp, B. W., Tanabe, S., Subramanian, A., Sericano, J. L., Wade, T. L., et al. (2016). Edward D. Goldberg's proposal of "the Mussel Watch": Reflections after 40 years. Mar. Pollut. Bull. 110, 501-510. doi: 10.1016/ j.marpolbul.2016.05.074

Gagnaire, B., Frouin, H., Moreau, K., Thomas-Guyon, H., and Renault, T. (2006). Effects of temperature and salinity on haemocyte activities of the Pacific oyster, Crassostrea gigas (Thunberg). Fish Shellfish Immnol. 20, 536-547. doi: 10.1016/ j.fsi.2005.07.003

Goldberg, E. (1975). The mussel watch - A first step in global marine monitoring. Mar. Pollut. Bull. 6:111. doi: 10.1016/0025-326x(75)90271-4

Gonzalez, J. G., and Yevich, P. (1976). Responses of an estuarine population of the blue mussel Mytilus edulis to heated water from a steam generating plant. Mar. Biol. 34, 177-189. doi: 10.1007/bf00390760

Han, G., Wnag, W., and Dong, Y. (2020). Effects of balancing selection and microhabitat temperature variations on heat tolerance of the intertidal black mussel Septifer virgatus. Intergr. Zool. 15, 416-427. doi: 10.1111/1749-4877. 12439

Harley, C. D. G. (2008). Tidal dynamics, topographic orientation, and temperaturemediated mass mortalities on rocky shores. Mar. Ecol. Prog. Ser. 371, 37-46. doi: $10.3354 /$ meps07711

Hégaret, H., da Silva, P. M., Wikfors, G. H., Haberkorn, H., Shumway, S. E., and Soudant, P. (2011). In vitro interaction between several species of harmful algae and haemocytes of bivalve molluscs. Cell Biol. Toxicol. 27, 249-266. doi: 10.1007/s10565-011-9186-6

Hégaret, H., Wikfors, G. H., and Soudant, P. (2003). Flow cytometric analysis of haemocytes from eastern oysters, Crassostrea virginica, subjected to a sudden temperature elevation: II. Haemocyte functions: aggregation, viability, phagocytosis, and respiratory burst. J. Exp. Mar. Bio. Ecol. 293, 249-265. doi: 10.1016/s0022-0981(03)00235-1

Hine, P. M. (1999). The inter-relationship of bivalve haemocytes. Fish Shellfish Immunol. 9, 367-385. doi: 10.1006/fsim.1998.0205

Hong, H. K., Donaghy, L., and Choi, K. S. (2014). Flow cytometric studies on the morphology and immunological functions of hemocytes in the Iwagaki oyster Crassostrea nippona. Fish. Sci. 80, 969-976. doi: 10.1007/s12562-014-0777-z

Hong, H. K., Donaghy, L., and Choi, K. S. (2019). Flow cytometric characterization of hemocytes of the abalone Haliotis diversicolor (Reeve, 1846) and effects of air exposure stresses on hemocyte parameters. Aquaculture 506, 401-409. doi: 10.1016/j.aquaculture.2019.04.001

Hong, H. K., Donaghy, L., Kang, C. K., and Choi, K. S. (2016). Substantial changes in hemocyte parameters of Manila clam Ruditapes philippinarum two years after the Hebei Spirit oil spill off the west coast of Korea. Mar. Pollut. Bull. 108, 171-179. doi: 10.1016/j.marpolbul.2016.04.033

Hong, H. K., Kang, H. S., Le, T. C., and Choi, K. S. (2013). Comparative study on the hemocytes of subtropical oysters Saccostrea kegaki (Torigoe \& Inaba, 1981), Ostrea circumpicta (Pilsbry, 1904), and Hyotissa hyotis (Linnaeus, 1758) in Jeju Island, Korea: Morphology and functional aspect. Fish Shellfish Immunol. 35, 2020-2025. doi: 10.1016/j.fsi.2013.09.022

Incze, L. A., Lutz, R. A., and Watling, L. (1980). Relationships between effects of environmental temperature and seston on growth and mortality of Mytilus edulis in a temperate Northern estuary. Mar. Biol. 57, 147-156. doi: 10.1007/ bf00390733

IPCC (2018). Global Warming of $1.5^{\circ} \mathrm{C}$. Intergovernmental Panel on Climate Change. Sweden: IPCC.

Iwasaki, K. (1995). Comparison of mussel bed community between two intertidal Mytilids Septifier virgatus and Hormomya mutabilis. Mar. Biol. 123, 109-119. doi: $10.1007 / \mathrm{bf} 00350329$

Jamili, S., Salimi, L., Motalebi, A., and Rostami-Beshman, M. (2009). Morphological and structural characteristics of the hemocytes of the Anodonta cygnea. Res. J. Environ. Sci. 3, 218-224. doi: 10.3923/rjes.2009.218.224

Jansen, J. M., Pronker, A. E., Kube, S., Sokolowski, A., Sola, J. C., Marquiegui, M. A., et al. (2007). Geographic and seasonal patterns and limits on the adaptive response to temperature of European Mytilus spp. and Macoma balthica populations. Oecologia 154, 23-34. doi: 10.1007/s00442-007-0808-x

Jauzein, C., Donaghy, L., and Volety, A. K. (2013). Flow cytometric characterization of hemocytes of the sunray venus clam Macrocallista nimbosa and influence of salinity variation. Fish Shellfish Immunol. 35, 716-724. doi: 10.1016/j.fsi.2013. 06.003

Kawai, T., and Tookeshi, M. (2004). Variable modes of facilitation in the upper intertidal: goose barnacles and mussels. Mar. Ecol. Prog. Ser. 272, 203-213. doi: $10.3354 /$ meps 272203

Kim, J. H., Lee, H. M., Cho, Y. G., Shin, J. S., Yoo, J. W., Choi, K. S., et al. (2020). Flow cytometric characterization of the hemocytes of blood cockles Anadara broughtonii (Schrenck, 1867), Anadara kagoshimensis (Lischke, 1869), and Tegillarca granosa (Linnaeus, 1758) as a biomarker for coastal environmental monitoring. Mar. Pollut. Bull. 160:111654. doi: 10.1016/j.marpolbul.2020. 111654

Lee, Y., Ni, G., Shin, J., Kim, T., Kern, E. M. A., Kim, Y., et al. (2020). Phylogeography of Mytiliisepta virgate (Mytilidae: Bivalvia) in the northwestern Pacific: cryptic mitochondrial lineages and mito-nuclear discordance. Mol. Phylogent. Evol. 157:107037. doi: 10.1016/j.ympev.2020.107037

Leung, J. Y., Connell, S. D., and Russell, B. D. (2017). Heatwaves diminish the survival of a subtidal gastropod through reduction in energy budget and depletion of energy reserves. Sci. Rep. 7:17688. doi: 10.1038/s41598-017-16 341-1

Liu, J. H., and Morton, B. (1994). The temperature tolerances of Tetraclita squamosa (Crustacea: Cirripedia) and Septifer virgatus (Bivalvea: Mytilidae) on a sub-tropical rocky shore in Hong Kong. J. Zoo. Lond. 234, 325-339.

Lutaenko, K. A., and Noseworthy, R. G. (2019). Contribution to the knowledge of the marine bivalve mollusk fauna of Gangwon Province, Korea. J. Asia. Pac. Biodivers. 12, 14-44. doi: 10.1016/j.japb.2018.07.009

Mackenzie, C. L., Lynch, S. A., Culloty, S. C., and Malham, S. K. (2014). Future oceanic warming and acidification alter immune response and disease status in a commercial shellfish species, Mytilus edulis L. PLoS One 9:e99712. doi: 10.1371/journal.pone.0099712

Matozzo, V., and Marin, M. (2011). Bivalve immune responses and climate changes: is there is a relationship. ISJ-Invert. Surviv. J. 8, 70-77.

Matozzo, V., Chinellato, A., Munari, M., Finos, L., Bressan, M., and Marin, M. G. (2012). First evidence of immunomodulation in bivalves under seawater acidification and increased temperature. PLoS One 7:e33820. doi: 10.1371/ journal.pone. 0033820

Meehl, G. A., and Tebaldi, C. (2004). Morea intense, more frequent, and longer lasting heat waves in the $21^{\text {st }}$ century. Science 305, 994-997. doi: 10.1126/ science.1098704 
Monari, M., Matozzo, V., Foschi, J., Cattani, O., Serrazanetii, G. P., and Marin, M. G. (2007). Effects of high temperatures on functional responses of haemocytes in the clam Chamelea gallina. Fish Shellfish Immunol. 22, 98-114. doi: 10.1016/j.fsi.2006.03.016

Mosca, F., Narcisi, V., Calzetta, A., Gioia, L., Finoia, M. G., Latini, M., et al. (2013). Effects of high temperature and exposure to air on mussel (Mytilus galloprovincialis, Lmk 1819) hemocyte phagocytosis: Modulation of spreading and oxidative response. Tissue Cell 45, 198-203. doi: 10.1016/j.tice.2012.12.002

Nikitaki, Z., Hellweg, C. E., Georgakilas, A. G., and Ravanat, J. L. (2015). Stressinduced DNA damage biomarkers: application and limitations. Front. Chem. 3:35. doi: 10.3389/fchem.2015.00035

Oliver, E. C. J., Donat, M. G., Burrows, M. T., Moore, B. P., Smale, D. A., Alexander, L. V., et al. (2018). Longer and more frequent marine heatwaves over the past century. Nat. Commun. 9:1324.

Paillard, C., Allam, B., and Oubella, R. (2004). Effect of temperature on defence parameters in Manila clam Ruditapes philippinarum challenged with Vibrio tapetis. Dis. Aquat. Org. 59, 249-262. doi: 10.3354/dao059249

Pansch, C., Scotti, M., Barboza, F. R., Al-Janabi, B., Brakel, J., Briski, E., et al. (2018). Heat waves and their significance for a temperature benthic community: A near-natural experimental approach. Glob. Change Biol. 24, 4357-4367. doi: $10.1111 /$ gcb. 14282

Parisi, M. G., Mauro, M., Sarà, G., and Cammarata, M. (2017). Temperature increases, hypoxia, and changes in food availability affect immunological biomarkers in the marine mussel Mytilus galloprovincialis. J. Comp. Physiol. B 187, 1117-1126. doi: 10.1007/s00360-017-1089-2

Perkins-Kirkpatrick, S. E., and Lewis, S. C. (2020). Increasing trends in regional heatwaves. Nat. Commun. 11:3357.

Petes, L. E., Menge, B. A., and Murphy, G. D. (2007). Environmental stress decreases survival, growth, and reproduction in New Zealand mussels. J. Exp. Mar. Bio. Ecol. 351, 83-91. doi: 10.1016/j.jembe.2007.06.025

Pipe, R. K., and Coles, J. A. (1995). Environmental contaminants influencing immune function in marine bivalve molluscs. Fish Shellfish Immmunol. 5, 581-595. doi: 10.1016/s1050-4648(95)80043-3

Rahman, M. A., Henderson, S., Miller-Ezzy, P., Li, X. X., and Qin, J. G. (2019). Immune response to temperature stress in three bivalve species: Pacific oyster Crassostrea gigas, Mediterranean mussel Mytilus galloprovincialis and mud cockle Katelysia rhytiphora. Fish Shellfish Immunol. 86, 868-874. doi: 10.1016/j. fsi.2018.12.017

Renault, T. (2015). Immunotoxicological effects of environmental contaminants on marine bivalves. Fish Shellfish Immunol. 46, 88-93. doi: 10.1016/j.fsi.2015. 04.011

Robinson, P. J. (2001). On the definition of a heat wave. J. Appl. Meteorol. Climatol. $40,762-775$.

Seuront, L., Nicastro, K. R., Zardi, G. I., and Goberville, E. (2019). Decreased thermal tolerance under recurrent heat stress conditions explains summer mortality of the blue mussel Mytilus edulis. Sci. Rep. 9, 1-14. doi: 10.1038/ s41598-019-53580-w

Shanks, A. L., Rasmuson, L. K., Valley, J. R., Jarvis, M. A., Salant, C., Sutherland, D. A., et al. (2019). Marine heat waves, climate change, and failed spawning by coastal invertebrates. Limnol. Oceanogr. 65, 627-636.

Silva-Aciares, F., Moraga, D., Auffret, M., and Tanguy, A. (2013). Transcriptomic and cellular response to bacterial challenge (Pathogenic Vibrio parahaemolyticus) in farmed juvenile Haliotis rufescens fed with or without probiotic diet. J. Invertebr. Pathol. 113, 163-176.

Smale, D. A., Wernberg, T., Oliver, E. C. J., Thomsen, M., Harvey, B. P., Straub, S. C., et al. (2019). Marine heatwaves threaten global biodiversity and the provision of ecosystem services. Nat. Clim. Change 9, 306-312. doi: 10.1038/ s41558-019-0412-1

Suchanek, T. H. (1978). The ecology of Mytilus edulis L. in exposed rocky intertidal communities. J. Exp. Mar. Bio. Ecol. 31, 105-120. doi: 10.1016/0022-0981(78) 90139-9
Sutherland, J. P. (1970). Dynamics of high and low populations of the limpet, Acmaea scabra (Gould). Ecol. Monogr. 40, 169-188. doi: 10.2307/194 2294

Tsuchiya, M. (1983). Mass mortality in a population of the mussel Mytilus edulis L. caused by high temperature on rocky shores. J. Exp. Mar. Biol. Ecol. 66, 101-111. doi: 10.1016/0022-0981(83)90032-1

Vazzana, M., Celi, M., Maricchiolo, G., Genovese, L., Corrias, V., Quinci, E. M., et al. (2016). Are mussels able to distinguish underwater sounds? Assessment of the reactions of Mytilus galloprovincialis after exposure to lab-generated acoustic signals. Comp. Biochem. Physiol., Mol. Integr. Physiol. 201, 61-70. doi: 10.1016/j.cbpa.2016.06.029

Vazzana, M., Ceraulo, M., Mauro, M., Papale, E., Dioguardi, M., Mazzola, S., et al. (2020). Effects of acoustic stimulation on biochemical parameters in the digestive gland of Mediterranean mussel Mytilus galloprovincialis (Lamarck, 1819). J. Acoust. Soc. Am. 147, 2414-2422. doi: 10.1121/10.000 1034

Wallis, R. L. (1975). Thermal tolerance of Mytilus edulis of Eastern Australia. Mar. Biol. 30, 183-191. doi: 10.1007/bf00390741

Wang, W. X., and Dei, R. C. H. (1999). Factors affecting trace element uptake in the black mussel Septifer virgatus. Mar. Ecol. Prog. Ser. 186, 161-172.

Weiskopf, S. R., Rubenstein, M. A., Crozier, L. G., Gaichas, S., Griffis, R., Halofsky, J. E., et al. (2020). Climate change effects on biodiversity, ecosystems, ecosystem services, and natural resource management in the United States. Sci. Total Environ. 733:137782.

Weitzman, B., Konar, B., Iken, K., Cloetti, H., Monson, D., Suryan, R., et al. (2021). Changes in rocky intertidal community structure during a marine heatwave in the Northern Gulf of Alaska. Front. Mar. Sci. 8:556820.

Well, H. W., and Gray, I. E. (1960). The seasonal occurrence of Mytilus edulis on the Carolina coast as a result of transport around Cape Hatteras. Biol. Bull. 119, 550-559. doi: 10.2307/1539267

Wethey, D. S. (1984). Sun and shade mediate competition in the barnacles Chthamalus and Semibalanus: a field experiment. Biol. Bull. Rev. 167, 176-185. doi: $10.2307 / 1541346$

Wu, F., Lu, W., Shang, Y., Kong, H., Li, L., Sui, Y., et al. (2016). Combined effects of seawater acidification and high temperature on hemocyte parameters in the thick shell mussel Mytilus coruscus. Fish Shellfish Immunol. 56, 554-562. doi: 10.1016/j.fsi.2016.08.012

Yang, H. S., Hong, H. K., Doanghy, L., Noh, C. H., Park, H. S., Kim, D. S., et al. (2015). Morphology and Immune-related Activities of Hemocytes of the Mussel Mytilus coruscus (Gould, 1861) from East Sea of Korea. Ocean Sci. J. 50, 1-9.

Yu, J. H., Song, J. H., Choi, M. C., and Park, S. W. (2009). Effects of water temperature change on immune function in surf clams, Mactra veneriformis (Bivalvia: Mactridae). J. Invertebr. Pathol. 102, 30-35. doi: 10.1016/j.jip.2009.06. 002

Conflict of Interest: The authors declare that the research was conducted in the absence of any commercial or financial relationships that could be construed as a potential conflict of interest.

Publisher's Note: All claims expressed in this article are solely those of the authors and do not necessarily represent those of their affiliated organizations, or those of the publisher, the editors and the reviewers. Any product that may be evaluated in this article, or claim that may be made by its manufacturer, is not guaranteed or endorsed by the publisher.

Copyright (c) 2021 Hong, Kim, Kim, Kajino and Choi. This is an open-access article distributed under the terms of the Creative Commons Attribution License (CC BY). The use, distribution or reproduction in other forums is permitted, provided the original author(s) and the copyright owner(s) are credited and that the original publication in this journal is cited, in accordance with accepted academic practice. No use, distribution or reproduction is permitted which does not comply with these terms. 